\title{
The Antiproliferative Activity and Molecular Docking Studies of Some Sulfonamides against Cancer Cell Lines Compared to Normal Cells
}

\author{
Abdel-Mohsen M. Soliman ${ }^{1 *}$, Mohsen M. Kamel' ${ }^{1}$, Ahmad F. Eweas ${ }^{1}$ Joanna \\ Wietrzyk $^{2}$, Magdalena Milczarek ${ }^{2}$ \\ ${ }^{1}$ Department of Therapeutic Chemistry National Research Centre, El-Buhouth St., \\ P.O. 12622, Dokki, Giza, Egypt. \\ ${ }^{2}$ Laboratory of Experimental Anticancer Therapy, Hirszfeld Institute of Immunology \\ and Experimental Therapy, Polish Academy of Sciences, Rudolfa Weigla 12, 53-114 \\ Wroclaw, Poland.
}

\begin{abstract}
COME new and known substituted 1,2,3,4-tetrahydroacridines incorporated at their position

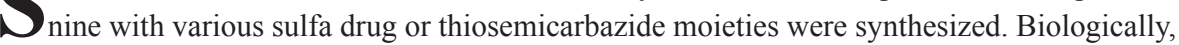
these compounds were investigated for their antiproliferative activity against human breast cancer (MCF-7) cell line compared to murine fibroblast normal cell line (BALB/3T3). The results were calculated as the $\mathrm{IC}_{50}$ (inhibitory concentration 50\%) compared with Cisplatin as control. Furthermore, a docking simulation study was carried out to predict the inhibitory mode of action of the most active compounds.
\end{abstract}

Keywords: Antiproliferative activity; 1,2,3,4-tetrahydroacridines; MCF-7; BALB/3T3 cell line, Molecular docking.

\section{Introduction}

Tetrahydroacridine derivatives are widely used in medicine as pharmaceutical agents [17]. Most members of this class of compounds are based on 9-substituted amino or anilino tetrahydroacridine scaffolds, paying special attention to the substituent effects in the acridine and the aniline rings on the DNA binding ability and cytotoxicity [7]. Also, some members of these compounds are used as memory enhancing agents $[1,2]$, acetyl choline esterase inhibitors [3, 4], antimicrobial agents [6] and anticancer agents[7]. On the other hand, sulfanilamides are reported to produce useful application as chemotherapeutic agents especially against pathogenic bacteria and tumor cells [8]. In the present study, it was of interest to investigate the biological activity of some new and known [9] tetrahydroacridine derivatives incorporated at position 9 with sulfa drug or phenyl isothiosemicarbazide moieties as antiproliferative agents against cancer and normal cell lines with more efficiency and biosafety margins. In chemotherapy, antiproliferative agents are compounds used to shrink tumors and/or to stop the cancer cells from growing and spreading. For example, Cisplatin, which is used to treat various types of cancer by damaging DNA and inhibiting DNA synthesis is a well-known important antineoplastic agent [10].

\section{Results and Discussion}

\section{Chemistry}

In continuation of our recent work in drug discovery program $[6,9]$, concerning synthesis of some new tetrahydroacridine derivatives of antidiabetic activity, the present work deals with the synthesis of a series of this class of compounds to be biologically investigated for their activity against cancer and normal cell lines compared to Cisplatin.

The known starting material of choice in the present study is 9-chloro-1,2,3,4tetrahydroacridine 1 [11], which is prepared by the reaction of cyclohexane and anthranilic acid followed by treatment with phosphorus oxychloride [7, 11].

Treatment of 1 with sulfanilamide and/or other sulfa drugs, namely, sulfa methoxazole, sulfa pyridine, sulfa guanidine and sulfa diazine in the presence of dilute hydrochloric acid, afforded the corresponding 4-(1,2,3,4-tetrahydroacridine9 -ylamino) benzene sulfonamide derivatives $2 \mathrm{a}-\mathrm{e}$ [9] (Scheme 1). 
On the other hand, reaction of the chloro tetrahydroacridine 1 with hydrazine hydrate in butanol under reflux for $8 \mathrm{~h}$, gave the known (1,2,3,4-tetrahydroacridine -9-yl)hydrazine derivatives 3 [7, 12]. Reaction of 3 with phenyl isothiocyante in ethyl alcohol at reflux temperature afforded the corresponding 1-(1,2,3,4-tetrahydroacridine-9-yl)4-phenyl
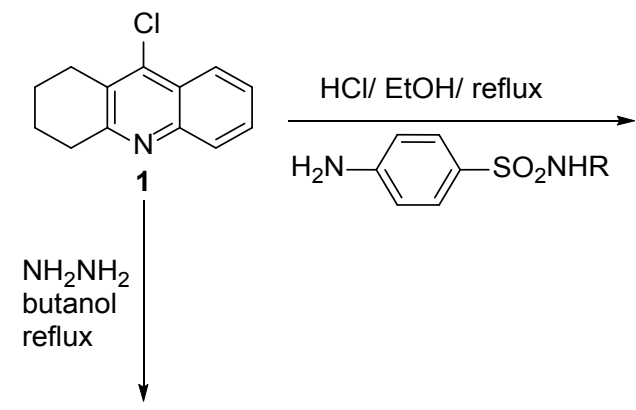<smiles>S=CNc1ccccc1</smiles><smiles>NNc1c2c(nc3ccccc13)CCCC2</smiles><smiles>[SbH2]N[SbH2]</smiles><smiles>CC(C)NNc1c2c(nc3ccccc13)CCCC2</smiles>

4 thiosemicarbazide 4 [13], which upon cyclocondensation with chloroacetyl chloride, gave the corresponding $\mathrm{N}$-phenyl thiazolidinone derivative 5 (Scheme 1).

Compounds 2a-e, 3 and 4 were tested for their antiproliferative activity against cancer and normal cell lines. 2a-e<smiles>O=C(Cl)C(Cl)Cl</smiles>

5<smiles>[R]Cc1cc(C)no1</smiles>

\section{Scheme 1}

\section{Antiproliferative activity}

The results were calculated as the $\mathrm{IC}_{50}$ (inhibitory concentration 50\%), the concentration of tested compound which inhibits $50 \%$ of the cells population. $\mathrm{IC}_{50}$ values were calculated for each experiment separately and mean values \pm $\mathrm{SD}$ are presented in the table. Every compound at each concentration was tested in triplicate in a single experiment, which was repeated 3-5 times. The results of the studies on antiproliferative activity of tested compounds are summarized in (Table 1).

The tested compounds from 2a-e, 3 and 4 , show similar activity to each other against breast cancer cell line MCF-7 and this activity is weaker than in the case of Cisplatin. However, Cisplatin shows the same cytotoxic activity against cancer cells as well as normal cells $\left(\mathrm{IC}_{50}=2.97 \mu \mathrm{g} / \mathrm{mL}\right.$ for MCF7 and $2.18 \mu \mathrm{g} / \mathrm{mL}$ for BALB/3T3). Compounds 2a, 3 and 4 are also active against normal cell line BALB/3T3 but the rest of compounds did not show any cytotoxic activity against this cell line. This means that compounds $2 \mathrm{~b}-\mathrm{d}$ show selectivity in action. They inhibit the growth of cancer cells but without any cytotoxic effects on normal cells in the used range of concentrations.

\section{Molecular Docking Simulation}

To examine the mode of inhibitory action of the most active synthesized 9-Substituted 1,2,3,4-tetrahydroacridine derivatives on a molecular level, a docking simulation with DNA binding site of human TopoII- $\beta$ (PDB id: 3QX3) along with etoposide reference ligand was carried out using FlexX module in LeadIT 2.1.8 software- 
package (BioSolveIT GmbH, 2014). To validate the molecular docking protocol, etoposide (bound ligand) was initially docked into the crystal structure of the enzyme which was downloaded from the PDB server (www.rcsb.org). The docked ligand was found to have similar binding poses to the co-crystallized ligand.

The docking results of the reference drug etoposide binding energy were $-37.50 \mathrm{Kcal} /$ mol. Etoposide also shows hydrogen bonding interactions with Asp479 of topo II and DF12 of the DNA and hydrophobic interactions with Gly478, Gly504 and Arg503 of topo II in addition to DGF10 and DGF13 of the DNA. On the other hand, the tested compounds 2c, 2d, 3 and 4 showed moderate to high binding affinity towards the binding site in Topoisomerase II (3QX3) ranging from -24.49 to $-37.25 \mathrm{Kcal} / \mathrm{mol}$ (Table 2). Compound $2 \mathrm{c}$ showed the highest binding energy forming two hydrogen bonds with DA12 and DG13 segments of the DNA, in addition to multiple hydrophobic interactions with DNA fragments and amino acid residues of the target enzyme. Furthermore, compound $2 \mathrm{~d}$ showed the second highest binding energy $-36.88 \mathrm{Kcal} / \mathrm{mol}$ forming two hydrogen bonding interactions with DC8 and DT9 segments of the DNA, in addition to two more hydrogen bonds with Gln778 and Ala779 amino acid residues of the target enzyme. The $2 \mathrm{D}$ poses of the tested compounds interactions with Topoisomerase II (3QX3) are shown in (Fig. 1). From these results, we can conclude that the newly synthesized acridine derivatives have higher affinity towards the DNA binding site of the topoisomerase II $\beta$ rather than the protein itself, which is in accordance with the fact that acridine derivatives have DNA binding affinity agrees with the published data [14].

TABLE 1. Antiproliferative activity of new derivatives towards Breast cancer and Normal cell lines.

\begin{tabular}{ccc}
\hline & IC $_{\mathbf{5 0}} \pm \mathbf{S D}[\boldsymbol{\mu g} / \mathbf{m L}]$ & \\
\hline Compound & $\mathbf{M C F}-7$ & BALAB/3T3 \\
\hline Cisplatin & $2.97 \pm 0.73$ & $2.18 \pm 0.60$ \\
$2 \mathrm{a}$ & $63.66 \pm 16.83$ & $54.69 \pm 10.00$ \\
$2 \mathrm{~b}$ & $59.20 \pm 19.44$ & $\mathrm{Nd}$ \\
$2 \mathrm{c}$ & $38.08 \pm 7.64$ & $\mathrm{Nd}$ \\
$2 \mathrm{~d}$ & $49.05 \pm 5.37$ & $\mathrm{Nd}$ \\
$2 \mathrm{e}$ & $71.63 \pm 4.66$ & $\mathrm{Nd}$ \\
3 & $30.82 \pm 3.01$ & $37.14 \pm 1.36$ \\
4 & $33.24 \pm 2.95$ & $36.56 \pm 1.14$
\end{tabular}

Compounds were tested in concentration from 100 to $0.1 \mu \mathrm{g} / \mathrm{mL}$;

$\mathrm{Nd}$ : not detected in used concentrations;

TABLE 2: Docking Results of the active compounds using Leadit 2.1.8 software.

\begin{tabular}{ccccc}
\hline Compound NO. & $\begin{array}{c}\text { Affinity Score } \\
\text { Kcal/mol }\end{array}$ & $\begin{array}{c}\text { Lipophilic } \\
\text { Contribution score }\end{array}$ & Clash Score & $\begin{array}{c}\text { Ligand Entropy } \\
\text { Conformation Score }\end{array}$ \\
\hline $2 \mathrm{c}$ & -37.25 & -16.50 & 5.87 & 2.80 \\
$2 \mathrm{~d}$ & -36.88 & -13.60 & 6.38 & 2.80 \\
3 & -24.49 & -8.50 & 3.13 & 0.00 \\
4 & -35.28 & -13.77 & 4.82 & 0.00 \\
Etoposide & -37.50 & -18.73 & 7.69 & 0.00 \\
\hline
\end{tabular}

Egypt. J. Chem. 61, No.3 (2018) 


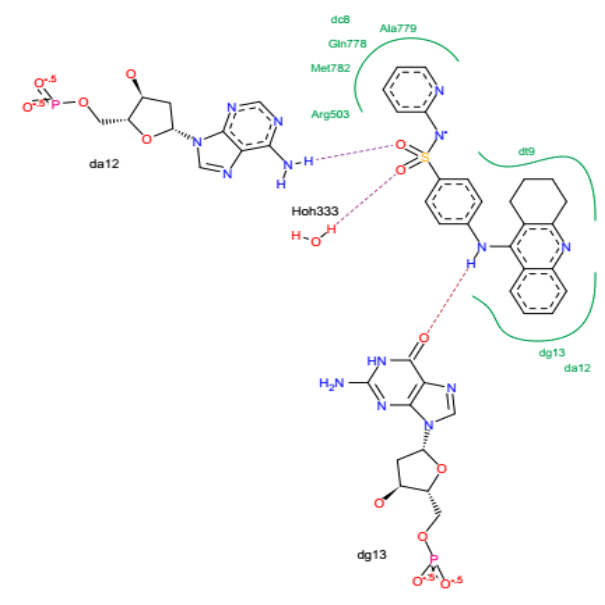

$2 c$

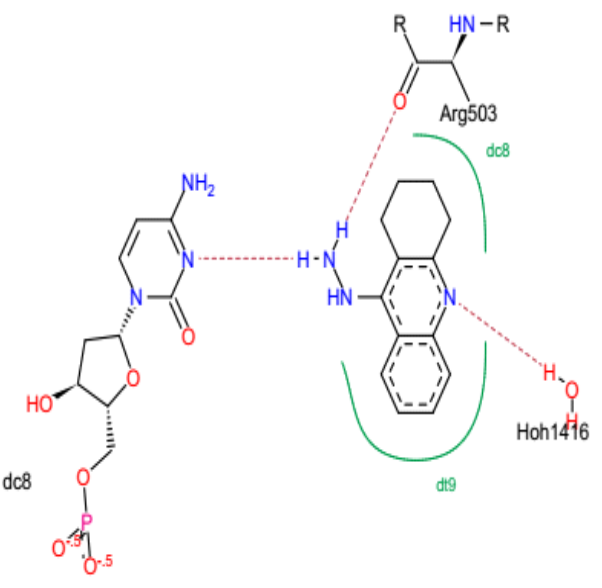

3

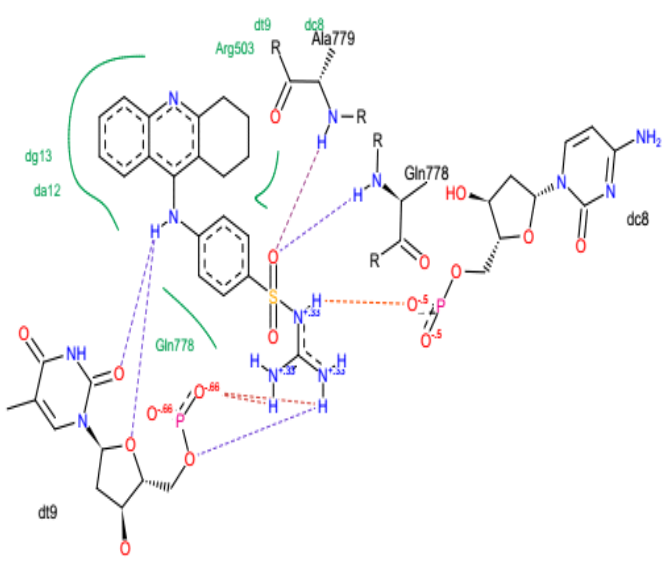

2d

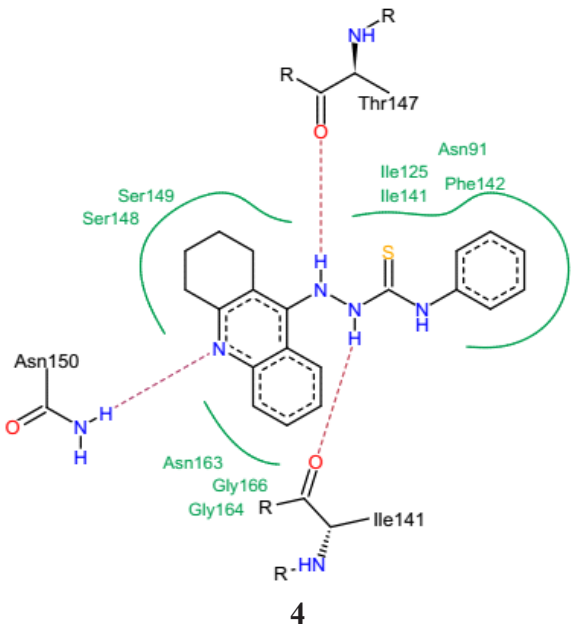

Fig. 1: Interaction of compounds $2 \mathrm{c}, 2 \mathrm{~d}, 3$ and 4 with the DNA binding site of human Topoisomerase II $\beta$.

\section{Experimental}

\section{Chemistry}

All melting points are uncorrected and were recorded on open capillary tubes using electro thermal apparatus 9100 (Electrothermal, Germany) digital melting points apparatus. Elemental micro analyses were carried out at Micro Analytical Unit, Cairo University, Giza -Egypt, using Vario Elementar and were found within $\pm 0.5 \%$ of the theoretical values. Infrared spectra were recorded on a Jasco FT/IR-6100, Fourier Transform Infrared Spectrometer at $\mathrm{cm}^{-1}$ scale using $\mathrm{KBr}$ disc technique at the Central Services Lab. NRC, Dokki, Giza, Egypt. ${ }^{1}$ HNMR spectra were determined by using a JEOL EX-270 NMR Spectrometer at Central Services Lab, NRC using dimethyl sulfoxide (DMSO- $\mathrm{d}_{6}$ ), and the chemical shifts were recorded in ppm relative to
TMS. Mass spectra were measured with GeMCQp 1000EX Shimadzu gas chromatography mass spectrometer (E.I 70eV, Japan). Follow up of the reactions and checking the purity of the compounds were made by TLC on silica gelprecoated aluminum sheets (Type 60 F254-Merck, Darmstadt, Germany) and the spots were detected by exposure to UV Lamp at $\lambda 254$ nanometers for a few seconds. Nomenclature given for the new compounds are according to the IUPAC System.

General Method for preparation of compounds $2 a-e$

A mixture of 9-chlorotetrahydroacridine 1 $(0.01 \mathrm{~mol})[11,13]$ and the appropriate sulfa drug, namely, sulfanilamide, sulfa methoxazole, sulfa pyridine, sulfa guanidine and /or sulfa diazine $(0.01 \mathrm{~mol})$ in $20 \mathrm{~mL}$ of absolute ethanol with few 
drops of dilute hydrochloric acid as a catalyst, was refluxed for $10-12 \mathrm{~h}$. The reaction mixture was concentrated in vacuo, cooled, and poured onto ice water. The resulting precipitate was recrystallized from the appropriate solvent to give compounds $2 \mathrm{a}-\mathrm{e}$, respectively.

4-((1,2,3,4-Tetrahydroacridin-9-yl)amino) benzenesulfonamide (2a)

m.p. $280^{\circ} \mathrm{C}$ (Lit. $280-282^{\circ} \mathrm{C}$ ) [9]; ${ }^{1} \mathrm{HNMR}$ (DMSO-d $\left.{ }_{6}, \mathrm{ppm}\right): 1.8\left(\mathrm{~m}, 4 \mathrm{H}, \mathrm{CH}_{2}, \mathrm{CH}_{2}\right), 2.4(\mathrm{t}$, $\left.2 \mathrm{H}, \mathrm{CH}_{2}\right), 3.25\left(\mathrm{t}, 2 \mathrm{H}, \mathrm{CH}_{2}\right)$, and7.1-8.43 (m, $8 \mathrm{H}$, aromatic protons) $7.82,7.95(\mathrm{~S}, 1 \mathrm{H}, \mathrm{NH}), \mathrm{MS}$ $\left(\mathrm{m} / \mathrm{z}\right.$, (relative abundance, \%)): $353\left(\mathrm{M}^{+}, 5\right)$ for $\mathrm{C}_{19} \mathrm{H}_{19} \mathrm{~N}_{3} \mathrm{O}_{2} \mathrm{~S}$.

N-(5-methylisoxazol-3-yl)-4-((1,2,3,4-tetrahydroacridin-9-yl) amino) benzene sulfonamide (2b)

(acetic acid); Yield 70\%; m.p. $250-255^{\circ} \mathrm{C}$; IR $\left(\mathrm{KBr}, \mathrm{cm}^{-1}\right)$ : 3420-3210 (br. NH), $1618(\mathrm{C}=\mathrm{N})$, $1145\left(\mathrm{~N}-\mathrm{SO}_{2}\right)$; $\mathrm{MS}(\mathrm{m} / \mathrm{z}$, (relative abundance, \%): $434\left(\mathrm{M}^{+}, 8\right)$; Anal. Calcd. for $\mathrm{C}_{23} \mathrm{H}_{22} \mathrm{~N}_{4} \mathrm{O}_{3} \mathrm{~S}$ : C, 63.58; H, 5.10; N, 12.89; Found: C, 64.00; H, $4.90 ; \mathrm{N}, 13.05 \%$.

$N$-(pyridin-2-yl)-4-((1,2,3,4-tetrahydroacridin-9yl)amino)benzenesulfonamide (2c)

(ethanol); m.p. $192^{\circ} \mathrm{C}$ (Lit. $192-194^{\circ} \mathrm{C}$ ) [9], ${ }^{1} \mathrm{HNMR}\left(\mathrm{DMSO}_{6}\right)$ : 1.8(m,m, 4H, $\left.\mathrm{CH}_{2}, \mathrm{CH}_{2}\right)$, $2.5\left(\mathrm{t}, 2 \mathrm{H}, \mathrm{CH}_{2}\right), 3.25\left(\mathrm{t}, 2 \mathrm{H}, \mathrm{CH}_{2}\right)$ and $7.8-8.5(12 \mathrm{H}$, aromatic protons) .

$N$-carbamimidoyl-4-((1,2,3,4-tetrahydroacridin9-yl)amino)benzenesulfonamide (2d)

(ethanol); Yield 75\%; m.p. 278-281 ${ }^{\circ} \mathrm{C}$; IR $\left(\mathrm{KBr}, \mathrm{cm}^{-1}\right)$ : $3375\left(\mathrm{NH}_{2}\right), 3420-3210$ (br. $\mathrm{NH}$ ), $1617(\mathrm{C}=\mathrm{N}), \quad 1336,1145 \quad\left(\mathrm{~N}-\mathrm{SO}_{2}\right)$; ${ }^{1} \mathrm{H}-\mathrm{NMR}$ (DMSO-d,$\delta / \mathrm{ppm}): 1.80\left(\mathrm{~m}, 4 \mathrm{H}, \mathrm{CH}_{2}, \mathrm{CH}_{2}\right)$, $2.40\left(\mathrm{t}, 2 \mathrm{H}, \mathrm{CH}_{2}\right), 3.50\left(\mathrm{t}, 2 \mathrm{H}, \mathrm{CH}_{2}\right), 7.10-7.45$ (m, $8 \mathrm{H} \mathrm{Ar-H}) ; \mathrm{MS}(\mathrm{m} / \mathrm{z}$, (relative abundance, \%)): $395\left(\mathrm{M}^{+}, 10\right)$; Anal. Calcd. for $\mathrm{C}_{20} \mathrm{H}_{21} \mathrm{~N}_{5} \mathrm{O}_{2} \mathrm{~S}$ : C, 60.74; H, 5.35; N, 17.71; S, 8.11; Found: C, $61.11 ; \mathrm{H}, 4.88 ; \mathrm{N}, 17.33 ; \mathrm{S}, 7.88 \%$.

N-(pyrimidin-2-yl)-4-((1,2,3,4-tetrahydroacridin9-yl)amino)benzenesulfonamide (2e)

(ethanol); m.p. $218{ }^{\circ} \mathrm{C}$ (Lit. 218-219 ${ }^{\circ} \mathrm{C}$ ) [9]; MS (m/z, (relative abundance, \%)): $433\left(\mathrm{M}^{+2}, 8\right)$; for $\mathrm{C}_{23} \mathrm{H}_{21} \mathrm{~N}_{5} \mathrm{O}_{2} \mathrm{~S}$.

$N$-phenyl-2-(1,2,3,4-tetrahydroacridin-9-yl) hydrazinecarbothioamide (4)

A mixture of 9-hydrazinotetrahydroacridine 3 (2.2 g; $0.01 \mathrm{~mol}$; prepared by reaction of a solution of compound $1(2.17 \mathrm{~g})$ with hydrazine hydrate $(0.15 \mathrm{~g})$ in $30 \mathrm{~mL}$ butanol under reflux for $8 \mathrm{~h}$; m.p. $\left.280^{\circ} \mathrm{C}[7,14]\right)$ and phenyl isothiocyanate $(1.2 \mathrm{~g}$,
$0.01 \mathrm{~mol}$ ) in $20 \mathrm{~mL}$ absolute ethanol, was allowed to reflux for $10 \mathrm{~h}$. The solid product obtained after cooling was recrystallized from ethanol to give $50 \%$ yield of 4 , m.p. $205-207^{\circ} \mathrm{C}$; IR $\left(\mathrm{KBr}, \mathrm{cm}^{-}\right.$ $\left.{ }^{1}\right)$ : 3378, $3234(2 \mathrm{NH}), 2929-2852(\mathrm{CH}), 1620$ $(\mathrm{C}=\mathrm{N}) ; \mathrm{MS}(\mathrm{m} / \mathrm{z}$, (relative abundance, \%)): 348 $\left(\mathrm{M}^{+}, 4\right)$; Anal. Calcd. for $\mathrm{C}_{20} \mathrm{H}_{20} \mathrm{~N}_{4} \mathrm{~S}: \mathrm{C}, 68.93 ; \mathrm{H}$, 5.79; N, 16.08; Found: C, C, 68.22; H, 6.05; N, $16.33 \%$.

3-Phenyl-2-(2-(1,2,3,4-tetrahydroacridin-9-yl) hydrazono)thiazolidin-4-one (5)

A mixture of compound $4(0.33 \mathrm{~g} ; 0.005$ $\mathrm{mol})$ and chloroacetylchloride $(0.25 \mathrm{~g}, 0.01 \mathrm{~mol})$ in $20 \mathrm{~mL}$ dry acetone, was refluxed for $8 \mathrm{~h}$. The reaction mixture was reduced to half of its volume in vacuo, cooled and the product was crystallized from DMF/ethanol to give 30\% yield of 5, m.p. $198^{\circ} \mathrm{C}$; IR $\left(\mathrm{KBr}, \mathrm{cm}^{-1}\right): 3370,3230(2 \mathrm{NH})$, $1700(\mathrm{C}=\mathrm{O}), 1625(\mathrm{C}=\mathrm{N}){ }^{1} \mathrm{H}$ NMR (DMSO-d6, ppm); $1.8\left(\mathrm{~m}, 4 \mathrm{H}, \mathrm{CH}_{2}, \mathrm{CH}_{2}\right), 2.5\left(\mathrm{t}, 2 \mathrm{H}, \mathrm{CH}_{2}\right)$, $3.3\left(\mathrm{t}, 2 \mathrm{H}, \mathrm{CH}_{2}\right), 3.4\left(\mathrm{~s}, 2 \mathrm{H}, \mathrm{CH}_{2}\right.$, thiazolidinone ring),7.4-8.6(m, $9 \mathrm{H}$ aromatic protons); and 7, 6, $8.1(\mathrm{~S}, 1 \mathrm{H}, \mathrm{NH}) \mathrm{MS}(\mathrm{m} / \mathrm{z}$, (relative abundance, \%): $388\left(\mathrm{M}^{+}, 8\right)$; Anal. Calcd. for $\mathrm{C}_{22} \mathrm{H}_{20} \mathrm{~N}_{4} \mathrm{OS}$ : C, 68.02; H, 5.19; N, 14.42; Found: C, 68.48; H, $5.25 ; \mathrm{N}, 14.57 \%$.

\section{Antiproliferative activity}

Cells

Cell lines: MCF-7 (human breast cancer) and BALA/3T3 (murine fibroblast) were maintained in the Institute of Immunology and Experimental Therapy, Wroclaw, Poland. All cancer cell lines were obtained from American type culture collection (Rockville, Maryland, USA). MCF7 cells were cultured in Eagle medium (IIET, Wroclaw, Poland) and supplemented with $2 \mathrm{mM}$ L-glutamine, $10 \%$ fetal bovine serum (GE: healthcare, Longan, UT, USA). All culture media were also supplemented with antibiotic: 100 units'/mL streptomycin (Sigma-Aldrich Chemie $\mathrm{GmbH}$, Steinheim, Germany) and 100 units'/ $\mathrm{mL}$ penicillin (Polfa Tarchomin, SA, Warsaw, Poland). All cell lines were grown at $37^{\circ} \mathrm{C}$ with $5 \% \mathrm{CO}_{2}$ humidified atmosphere.

\section{Compounds}

Prior to usage, the compounds were dissolved in DMSO (stock solution $10 \mathrm{mg} / \mathrm{mL}$ ) and culture medium (1:9) to the concentration of $1 \mathrm{mg} / \mathrm{mL}$ and subsequently diluted in culture medium to reach the required concentration ranging from 100 to $0.1 \mu \mathrm{g} / \mathrm{mL}$. 


\section{Antiproliferative assay in vitro}

$24 \mathrm{~h}$ before addition of the tested compounds, the cells were plated in 96-wellplates (Sarstedt, Germany) at density of $1 \times 10^{4}$ cells per well. The assay was performed after $72 \mathrm{~h}$ exposure to varying concentration of the tested compounds. The in vitro cytotoxic effect of all compounds was examined using the SRB assay.

\section{SRB Cytotoxicity test}

The details of this technique were described by Skehan et al.[15], and the cells were attached to the bottom of plastic wells by fixing them with cold 50\% TCA (trichloroacetic acid, SigmaAldrich Chemie GmbH, Steinheim, Germany) on the top of the culture medium in each well. The plates were incubated at $4^{\circ} \mathrm{C}$ for $1 \mathrm{~h}$ and then washed five times with tap water. The cellular material fixed with TCA was stained with $0.4 \%$ sulphorhodamine B (SRB, Sigma-Aldrich Chemie GmbH, Steinheim, Germany) dissolved in $1 \%$ acetic acid (POCH, Gliwice, Poland) for $30 \mathrm{~min}$. Unbound dye was removed by rinsing ( 5 times) in 1\% acetic acid. The protein-bound dye was extracted with $10 \mathrm{mM}$ unbuffered Tris base (POCH, Gliwice, Poland) for determination of the optical density $(\lambda=540 \mathrm{~nm})$ in synergy H4 multimode microplate reader (BioTek Instruments USA).

\section{Molecular Docking}

All docking studies were performed using sing FlexX module in LeadIT 2.1.8 software package (BioSolveIT GmbH, 2014). A set of the most active cytotoxic new acridine derivatives including compounds 2c, 2d, 3 and 4 were compiled using ChemDraw, and the 3D structures were constructed using ChemBio3D ultra 12.0 software [Molecular Modeling and Analysis; Cambridge Soft Corporation, USA (2010)], then they were energetically minimized using MOPAC (semi empirical quantum mechanics), Job Type with 100 iterations and minimum RMS gradient of 0.01, and saved as SDF MolFile (*.sdf). The crystal structure of target enzyme topoisomerase II complexed with DNA (PDB code $=3 \mathrm{QX} 3$ ) was retrieved from the Protein Data Bank (http:// www.rcsb.org). The protein was loaded into Leadit 2.1.8 and the receptor components were chosen by selection of all chains in the protein. The binding site was defined by choosing the native ligand Etoposide as a reference ligand to which all coordinates were computed. Amino acids within radius $6.5 \mathrm{~A}^{\circ}$ were selected in the binding site. All chemical ambiguities of residues were left as default. Ligand binding was driven by enthalpy (classic Triangle matching). For scoring, all default settings were restored. Intra-ligand clashes were computed using clash factor $=0.6$. Maximum number of solutions per iteration $=200$. Maximum number of solutions per fragmentation $=200$. The base placement method was used as a docking strategy.

\section{References}

1. Recanatini M., Cavalli A., Belluti F., Piazzi L., Rampa A., Bisi A., Gobbi S., Valenti P., Andrisano V., Bartolini M., SAR of 9-amino-1, 2, 3, 4-tetrahydroacridine-based acetylcholinesterase inhibitors: synthesis, enzyme inhibitory activity, QSAR, and structure-based CoMFA of tacrine analogues. Journal Of Medicinal Chemistry.43, 2007-2018 (2000).

2. Rosini M., Andrisano V., Bartolini M., Melchiorre C., Tetrahydro-acridine and dithiolane derivatives. Google Patents; (2007).

3. Carlier P.R., Du D-M., Han Y., Liu J., Pang Y-P., Potent, easily synthesized huperzine A-tacrine hybrid acetylcholinesterase inhibitors. Bioorganic \& Medicinal Chemistry Letters.9, 2335-2338 (1999).

4. Ebeid M.Y. K.M., Ragab F., Nofal Z.M., Ahmed A.A.E., Zaghry W.A., El-Kady M.E., New 9-(p-substituted aniline) tetrahydroacridines as acetylcholine estrase inhibitors. Azhar Journal of Pharmaceutical Sciences 24, 114-132 (1999).

5. Dinesen J., Jacobsen J.P., Hansen F.P., Pedersen E.B., Eggert H., DNA intercalating properties of tetrahydro-9-aminoacridines. Synthesis and sodium-23 NMR spin-lattice relaxation time measurements. Journal of Medicinal Chemistry 3, 93-97 (1990).

6. Ebeid M., Kamel M., NofalZ., Ragab F., Zaghary W., El-Kady M., New antimicrobial 9-(p-heterocyclosubstituted anilino)-tetrahydroacridines. Egyptian Journal of Chemistry 49, 277-285 (2006).

7. Fathhalla O.A., Mohamed M.S., Farag M.A., Ismail R.S.A., Synthesis of certain tetrahydroacridine derivatives of anticipated medicinal value. Research on Chemical Intermediates 39, 3487-3505 (2013).

8. Kamel M.M., Ali H.I., Anwar M.M., Mohamed N.A., Soliman A.M., Synthesis, antitumor activity and molecular docking study of novel sulfonamideSchiff's bases, thiazolidinones, benzothiazinones and their C-nucleoside derivatives. European 
Journal Of Medicinal Chemistry 45, 572-580 (2010).

9. Megeed R.M.A., Ghanem H.Z., Kamel M.M., Bakeet M.F., Abdel-Hamid A-H.Z., Assessment of some synthesized novel 9-substituted tetrahydroacridine derivatives in diabetic disease management in rats. Egyptian Pharmaceutical Journal.16, 53(2017).

10. Pinto A.L., Lippard S.J., Sequence-dependent termination of in vitro DNA synthesis by cis-and trans-diamminedichloroplatinum (II). Proceedings of the National Academy of Sciences. 82, 46164619(1985).

11. Chen Y-L., Lu C-M., Chen I-L., Tsao L-T., Wang J-P., Synthesis and antiinflammatory evaluation of 9-anilinoacridine and 9-phenoxyacridine derivatives. Journal of Medicinal Chemistry.45, 4689-4694 (2002).

12. Patočka J., Bajgar J., Fusek J., 9-Hydrazino-1, 2, 3, 4-tetrahydroacridine, a competitive inhibitor of butyrylcholinesterase. Collection of Czechoslovak
Chemical Communications.42, 2975-2981(1977).

13. Soliman R., Hammouda N.A., Synthesis of new mercaptotriazoles with potential antibilharzial activity. Journal of Pharmaceutical Sciences.68, 1377-1381(1979).

14. Oppegard L.M., Ougolkov A.V., Luchini D.N., Schoon R.A., Goodell J.R., Kaur H., Billadeau D.D., Ferguson D.M., Hiasa H., Novel acridinebased compounds that exhibit an anti-pancreatic cancer activity are catalytic inhibitors of human topoisomerase II. European Journal of Pharmacology.602, 223-229 (2009).

15. Skehan P., Storeng R., Scudiero D., Monks A., McMahon J., Vistica D., Warren J.T., Bokesch H., Kenney S., Boyd M.R., New colorimetric cytotoxicity assay for anticancer-drug screening. JNCI: Journal of the National Cancer Institute. 82, 1107 1112 (1990).

(Received 14/2/2018; accepted $15 / 5 / 2018$ )

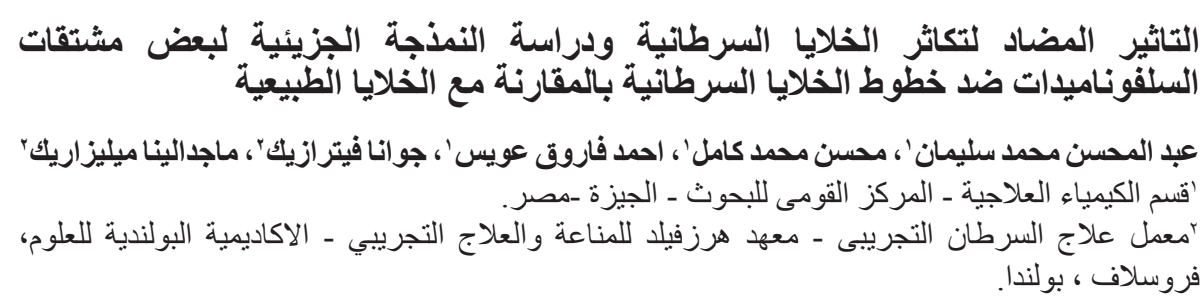

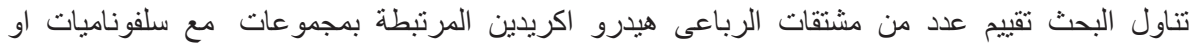

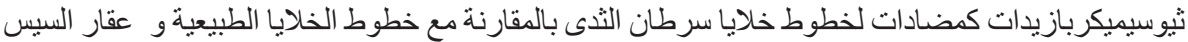

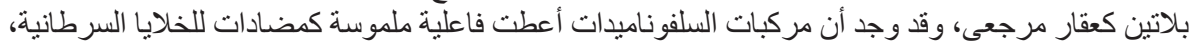

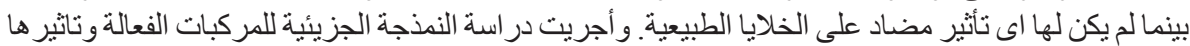

المثبط على أحد المستقبلات الانزيمية. 